\title{
The effectiveness of rational-emotional therapy and solution focused group therapy on social anxiety disorder in students of Shiraz University
}

\author{
Mansooreh Mahdiyar ${ }^{1}$, Shekoofeh Dadfarnia ${ }^{2}$, Habib Hadianfard ${ }^{3}$, Changiz Rahimi $^{4}$ \\ 1- Ph.D student in clinical psychology, Department of education and psychology, Shiraz university, Shiraz, Iran \\ (Corresponding Author). ORCID: 0000-0001-5241-625X E-mail: mansurehmahdiar@yahoo.com \\ 2- Ph.D student in clinical psychology, Department of education and psychology, Shiraz university, Shiraz, Iran. \\ ORCID: 0000-0002-9414-0586 \\ 3- Proffessor in clinical psychology, Department of education and psychology, Shiraz university, Shiraz, Iran. \\ ORCID: 0000-0002-1728-632X \\ 4- Proffessor in clinical psychology, Department of education and psychology, Shiraz university, Shiraz, Iran. \\ ORCID: 0000-0002-7180-364X
}

\section{Abstract}

Received: 22/02/2019

Accepted: 20/05/2019

Introduction: Despite the high prevalence and unpleasant consequences of social anxiety disorder in university students, little research has been done to determine the most effective treatment for SAD.

Aim: The aim of this study was to investigate and compare the effectiveness of rational-emotive and solution-focused brief therapy on reducing social anxiety symptoms.

Method: The research method was experimental with pretest-posttest design with a control group and two experimental groups .Using convenience sampling, 45 students with social anxiety symptoms were selected. Clinical interview and social phobia inventory were conducted to make certain that they satisfied the research criteria. Then they were randomly assigned to three groups ( 2 experimental and 1 control groups). The data were analyzed using analysis of covariance in SPSS-21.

Results: Showed that rational-emotive therapy and solution-focused therapy significantly reduced symptoms of social anxiety, but rational-emotive therapy was significantly more effective than solution-focused therapy.

Conclusion: Rational-emotive therapy and solution-focused therapy could be used to treat social anxiety symptoms. Although results showed rational- emotional therapy might be more appropriate treatment for students with social anxiety, further research is needed to confirm the findings of present study.

Keywords: Social anxiety disorder, Rational-emotional group therapy, Solution focused group therapy

How to cite this article : Mahdiyar M, Dadfarnia Sh, Hadianfard H, Rahimi Ch. Investigating the effectiveness of rational-emotional therapy and solution focused group therapy on social anxiety disorder in the students of Shiraz University. Shenakht Journal of Psychology and Psychiatry. 2019; 6 (3): 118-128 .URL: http://shenakht.muk.ac.ir/article-1-272-fa.pdf

Copyright $\odot 2018$ the Author (s). Published by Kurdistan University of Medical Sciences. This is an open access article distributed under the terms of the Creative Commons Attribution-Non Commercial License 4.0 (CCBY-NC), where it is permissible to download, share, remix, transform, and buildup the work provided it is properly cited. The work cannot be used commercially without permission from the journal. 


\title{
بررسى اثربخشى در مان تروهى عقلانى_عاطفى و درمان تروهى راه حل محور بر اضطراب اجتماعى در دانشجويان دانشكاه شيراز
}

\author{
منصوره مهدى يار'، شكوفه دادفرنيا'، حبيب هاديان فردّ، جنغيز رحيمى ' \\ ا. دانشجوى دكتراى روانشناسى بالينى، دانشكده علوم تربيتى و روانشناسى، دانشگاه شيراز، شيراز، فارس، اير ان (مولف مسئول). \\ ايميل:yahoo.com \\ r. دانشجوى د كتراى روانشناسى بالينى، دانشكده علوم ترييتى و روانشناسى، دانشخاه شيراز، شيراز، فارس، ايران.

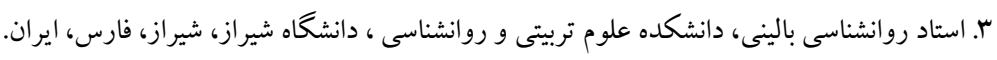

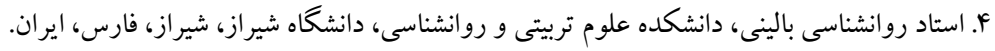

مقدمه: با وجود شيوع بالا و تبعات زياد اختلال اضطراب اجتماعى در جامعه دانشجويان، تاكنون مطالعات اندكى براى تعيين اثربخشترين درمان براى اين اختلال انجام شده است.

هدف: اين يزوهش با هدف بررسى و مقايسه اثربخشى درمان گروهى عقلانى -عاطفى و درمان گروهى راه حل محور انجام يذيرفت. روش: روش تحقيق از نوع آزمايشى با طرح ييش آزمون- هس آزمون با يك گروه كنترل و دو گروه آزمايش است. با استفاده از

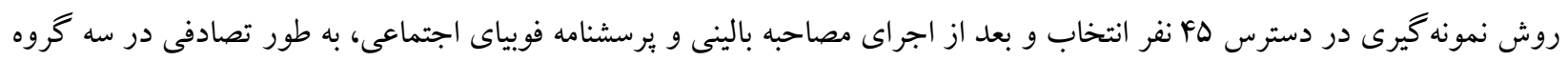

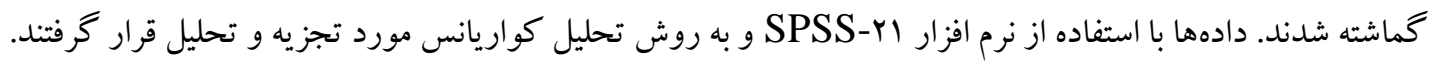
يافته ها: نتايج نشان داد كه هم درمان عقلانى -عاطفى و هم درمان راهحل محور در كاهش نشانهاى اضطراب اجتماعى تأثير معنادارى

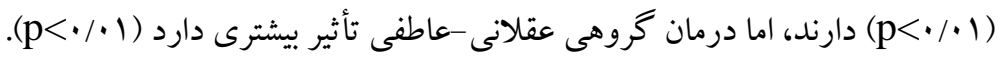

نتيجه كيرى: بــا توجـهـ بـه نتايــج بهدست آمده، مى توان از دو درمان گروهى راهحل محور و عقلانى -عاطفى بهعنوان روشـى

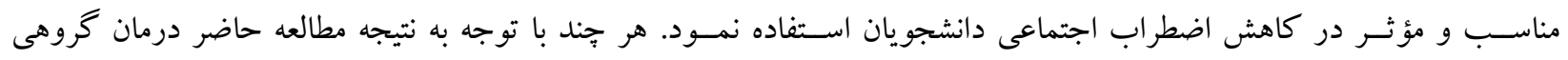
راهحل محور اثربخشى بيشترى رادر عمل نشان داد اما براى نتيجه گيرى قطعى درباره برترى آن نياز به ئزوهشهاى بهر بيشترى است. كليد وازهها: اضطراب اجتماعى، درمان گروهى عقلانى -عاطفى، درمان گروهى راهحل محور 
اضطراب اجتماعى صورت گرفته است و روشهاى

مقدمه

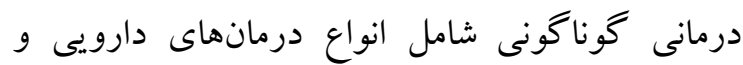
اختلال اضطراب اجتماعى به ترس شديد و افراطى از روانشناختى جهت بهبود اختلال اضطراب اجتماعى ارائهشده و به لحاظ تجربى نيز مورد تأييد واقعشدهاند

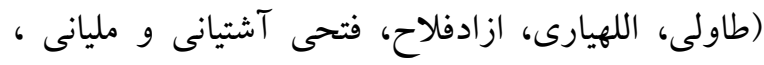

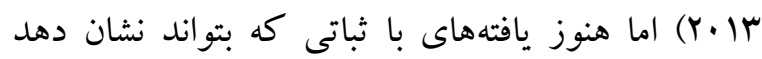

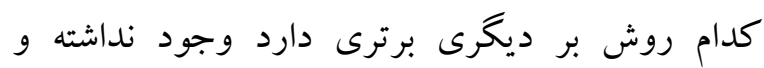
درنتيجه هنوز اتفاق نظر كافى بين صاحب نظران وجود ندارد. در حال حاضر درمان انتخابى اضطراب اجتماعى رفتاردرمانى شناختى از طريق گروه درمانى است. در اين رويكرد فرض بر اين است كه الكوى تفكر فرد و اجتناب از موقعيتهاى اجتماعى باعث تداوم اين اختلال مى شوند. در مورد ميزان اثربخشى درمانهاى شناختى - شئى رفتارى يزوهشهايى صورت گرفته است. براى مثال بير و

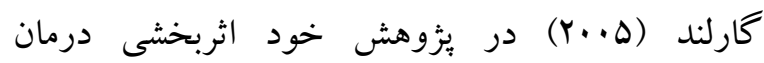
شناختى -رفتارى را در كاهش فوبى اجتماعى نشان دادند. در يثزوهش اسكيف و همكاران نتايج حاكى از تأثير معنادار درمان گروهى شناختى-رفتارى در مقابل درمان انفرادى شناختى -اجتماعى بود. در آمريكا مكى اوى و همكاران به مقايسه درمان شناختى رفتارى با درمان آموزش توجه و آموزش آرامبخشى يرداختند. نتايج نشان داد درمان شناختى-رفتارى در كاهش فوبى اجتماعى لهو تأثير بيشترى داشته است. در ايران نيز بزّوهش بوراحسان

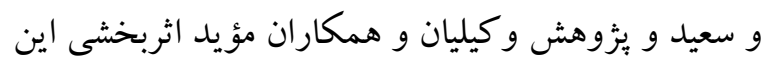

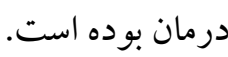
درمان عقلانى- عاطفى اليس يكى از درمان هاى شناختى - رفتارى است كه تاكنون در مورد اثربخشى آن بر اختلال اضطراب اجتماعى در ايران يُوهشى انجام

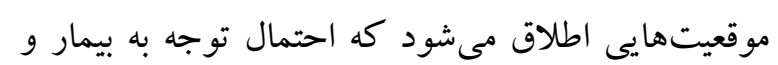
تجزيهو تحليل رفتار او وجود دارد. اين موقعيتها شامل تعاملات اجتماعى، مشاهده شدن و اجرا كردن در حضور ديخران است. مبتلايان به اين اختلال از اينكه در اين موقعيتها دجار خجالتزدگى شده يا مورد ارزيابى إنى ديخران قرار بحيرند، مىهراسند. ميزان شيوع اين اختلال

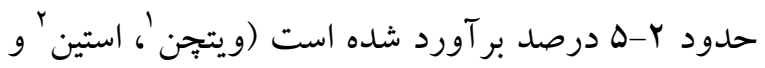
كسلر r، (1999). اين اختلال عملكرد تحصيلى، اجتماعى، خانوادگى و و شخصى و نيز بهرهورى اقتصادى فرد را به طور قابلملاحظهاى مختل مىسازد و مبتلايان را در معرض خطر بالاى ابتلا به اختلال افسردگى اساسى ثانوى بر مالى اضطراب اجتماعى و كاهش سطح كيفيت زندكى قرار مىدهد (قائدى، طاولى، بختيارى، مليانى و صحراگرد،

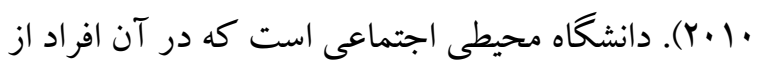
برقرارى ارتباط، مشاهده شدن و گاهى ارائه دادن در

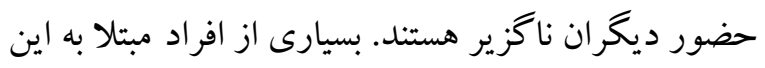

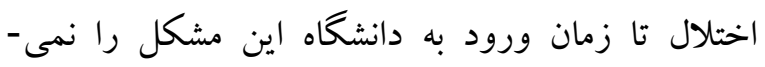
شناسند. آنها ممكن است براى اولين بار در مواجهه با بإن

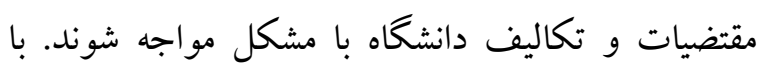
توجه به اهميت تعاملات در دانشگاه، اين اختلال مىتواند براى دانشجويان باعث ايجاد مشكلات و از دست دادن فرصتهاى بيشرفت زيادى شود. لذا درمان اين اختلال در دانشجويان بايد به طور خاص مورد توجه قرار كيرد. با توجه به تبعات اين اختلال و ميزان شيوع آن در جامعه، مطالعات زيادى براى ارائه درمانهاى مؤثر براى

\footnotetext{
${ }^{1}$ Wittchen

${ }^{2}$ Stein

${ }^{3}$ Kessler
} 
به كاررفته است و اثربخشى خود را در حوزهاى مختلف مانند درمان معتادين به سوءمصرف مواد و نوجوانان در معرض بحران و داراى مشكلات رفتارى

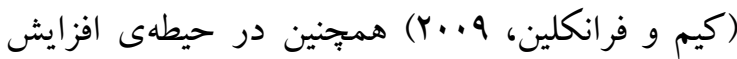
عملكرد تحصيلى و خودكار آمد يندارى دانش آموزان نشان داده است. درمان كوتاه مدت به ويزه براى درمان اختلالهاى خفيف و اختلالهاى ساز كارى مفيد واقع مىشود، اما اين درمان براى بيماران مزمن هم توصيهشده

$$
\text { است (حبيبى، 101 (Y). }
$$

به رغم آن كه تاريخجه درمان راه حل محور نسبتاً كو تاه است، اما به خاطر تأكيد بر تغييرات سريع درمانى و احترام به ديدكاه مراجع كه هر دو با فلسفه مراقبت از سلامتى ساز گارند، در سالهاى اخير موردتوجه بسيارى از مشاوران و متخصصان سلامت روان در سراسر دنيا قرار كرفته است (دشتىزاده، ساجدى، نظرى، داورى نيا و شاكرمى، ها •Y). علىرغم اين توجه گسترده و با وجود اين كه اثربخشى اين درمان براى برخى از اختلالات اضطرابى مثل اضطراب امتحان و اضطراب فراگير در يزوهشها مورد تائيد قرار كرفته است، تاكنون به يثوهشى به اثر بخشى اين درمان بر اضطراب اجتماعى

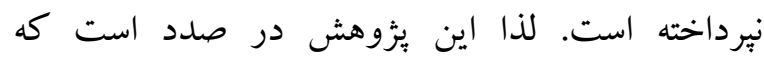
اثربخشى درمان كوتاه مدت راه حل مدار و درمان عقلانى-عاطفى را در گروهى از دانشجويان دختر دانشگاه شيراز بسنجد و مورد مقايسه قرار دهد. اهميت عملى يُوهش حاضر در اين است كه خجنانجه

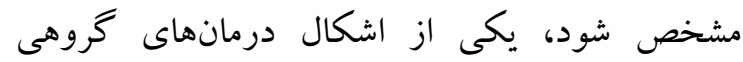
موردمطالعه در اين بثزوهش به طرز معنىدارى بر بقيه

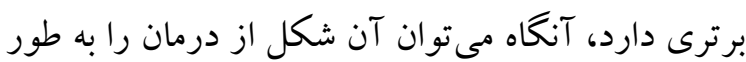
ويزه جهت استفاده در موقعيتهاى بالينى براى درمان
نشده است. اين در حالى است كه به نظر مى رسد با توجه به اينكه اين درمان هم هيجان و هم شناخت را مورد هدف قرار مى دهد براى اين گروه دانشجويان جوان

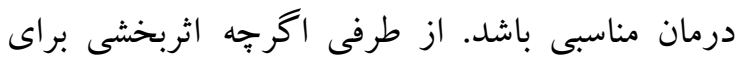
درمان اضطراب اجتماعى به خوبى به تأييد رسيده است، نتايج كارآزمايى هاى بالينى نشان دادهاند كه تعداد نسبتاً معدودى از افرادى كه درمان شناختى رفتارى را با هاب رعايت استانداردهاى لازمه آن دريافت نمودهاند، بعد از اتمام دوره درمان به عملكرد بهينه دست مى يابند (تيلور، 1999) با توجه به محدوديتهاى بالينى موجود در اثربخشى بهتر است كاربرد رويكردهاى رواندرمانى جايگزين براى درمان اضطراب اجتماعى در نظر گرفته شود (طاولى و همكاران، rا. r). يكى ديخر از درمانهايى كه در سالهاى اخير مورد توجه بسيارى از مشاوران و متخصصان سلامت روان در سراسر دنيا قرارگرفته است درمان كوتاه مدت راهحل محور است درمان راهحل محور بر گرفته از رويكرد بِ بستمدرن است كه در اوايل سال •191 در مركز خانواده درمانى

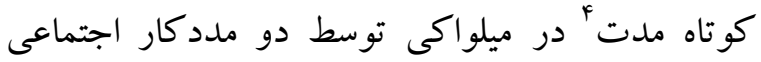

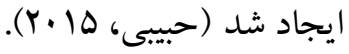
درمان كوتاه مدت راه حل مدار يكك رويكرد آينده محور و هدف محور است كه بر منابع مراجعه كنند كان تكيه مىزند اين درمان بهجاى مشكل، بر ارائه راهحل تمركز دارد و بهجاى جستجوى مشكلات كنونى و علل

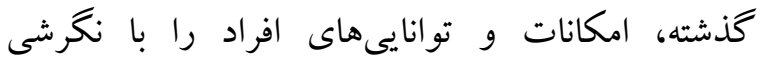
اميدوارانه و آيندهنگ جستجو مى كند (قديرى و حبيى،

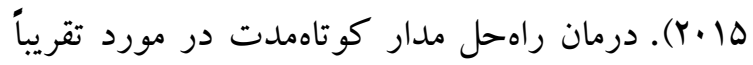
همهى اختلالهاى رفتارى و در تمام الخوهاى درمان

\footnotetext{
${ }^{4}$ Brief Family Therapy Center
} 
اوليهاى در زمينه دريافت تشخيص اضطراب اجتماعى بر اساس DSM-IV و بررسى آمادگى افراد براى شركت در گروه درمانى انجام شد و از افراد خواسته شد كه به فرم رضايت نامه و وبرسشنامه اضطراب اجتماعى باسخ كويند. از اين ميان جهل و ينج نفر از افراد مبتلا به اضطراب اجتماعى شناخته شدند كه به صورت تصادفى در دو گروه آزمايشى و گروه كنترل جاكذارى شدند. معيار ورود به اين مطالعه نمره بالاتر از نقطه برش در يرسشنامه اضطراب اجتماعى و تشخيص اضطراب اجتماعى بر اساس مصاحبه بالينى ساختاريافته بر مبناى

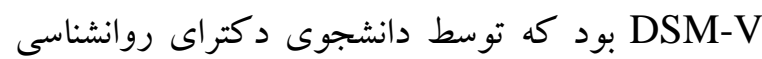

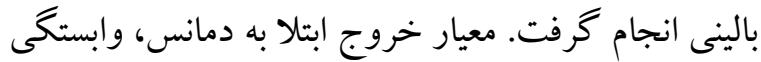
به مواد، اختلالات سايكوتيكك، دريافت هر كونه درمان روانشناختى همزمان و دريافت درمان دارويى از سه ماه بيش تاكنون بود. در مرحلهى بعد، گروه آزمايشى درمان عقلانى -عاطفى به

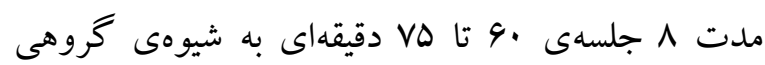
تحت درمان قرار كرفتند. اين ^ جلسه به مدت يكك ماه

به طول انجاميد.
اختلال فوبى اجتماعى بيشنهاد نمود .از طرفى همان كونه كه ذكر آن رفت، بررسى ادبيات تحقيق در ايران در ارتباط با موضوع حاضر نشان مىدهد كه در اين زمينه يزوهشى، كمبودهايى ورجود دارد. بنابراين انجام يثزهشهايى از اين نوع بر روى آزمودنىهاى ايرانى، ضرورتى اجتنابنايذير است. روش روش تحقيق در يُزوهش حاضر از نوع آزمايشى با طرح ييش آزمون- يس آزمون با يكك گروه كنترل و دو كروه آزمايش است. در اين تحقيق جامعلى بزوهش كليهى دانشجويان مبتلا به اضطراب اجتماعى در سال تحصيلى هودانشگاه شيراز بودهاند. روش نمونه گيرى از نوع در اصرئر دسترس است. براى اين كار ابتدا در دانشگاه و و خوابگاههاى آن اطلاعرسانى شد كه كسانى كه از علائمى مانند اضطراب هنگام ارائه و حضور در جمع رنج مىبرند مىتوانند در صورت تمايل نامنويسى نموده و در

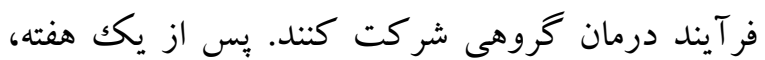
تمامى اسامى جمع آورى گرديد با آنها تماس گرفته شد و از آنها خواسته شد در يك جلسه براى آمادكى بيش از تشكيل گرووه شركت نمايند. در اين جلسه مصاحبه

\begin{tabular}{|c|c|}
\hline شرح جلسات & تعداد جلسات \\
\hline خوشامد گويى، معرفى اعضاو قوانين گروه & جلسه اول \\
\hline شناسايى افكار غيرمنطقى & 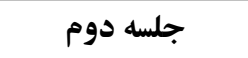 \\
\hline ״الش با افكار غيرمنطقى و جايخزينى آنها با افكار منطقى & جلسه سوم و جهارم \\
\hline تأكيد بر تكنيككهاى رفتارى مواجهه و حساسيت زدايى تدريجى & 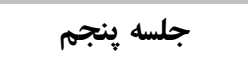 \\
\hline تكنيكهاى ريلكسيشن و يذيرش بى قيد و شرط خود & 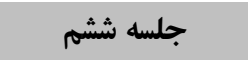 \\
\hline 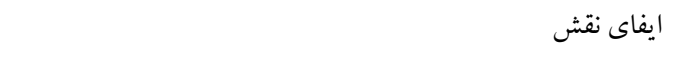 & جلسه هفتم \\
\hline 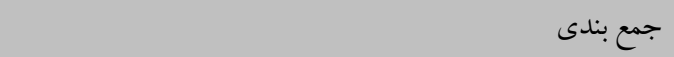 & جلسه هشتم \\
\hline
\end{tabular}




$$
\text { كروه آزمايشى راه حل محور هم در } 4 \text { جلسه به شرح زير به شيوه كروهى شر كت كردند؛ }
$$

جدول r خلاصه محتواى جلسات درمان راه حل محور

\begin{tabular}{|c|c|}
\hline شرح جلسات & شماره جلسات \\
\hline 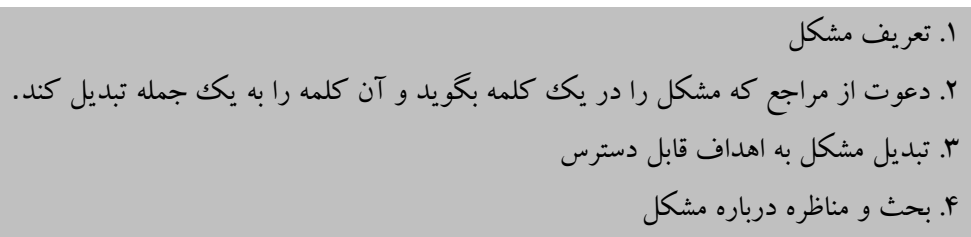 & جلسه اول \\
\hline 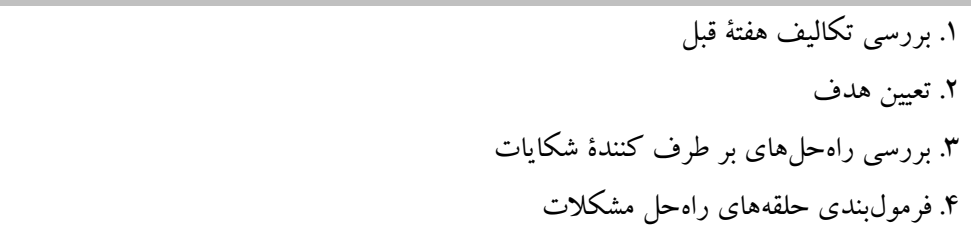 & جلسه دوم \\
\hline 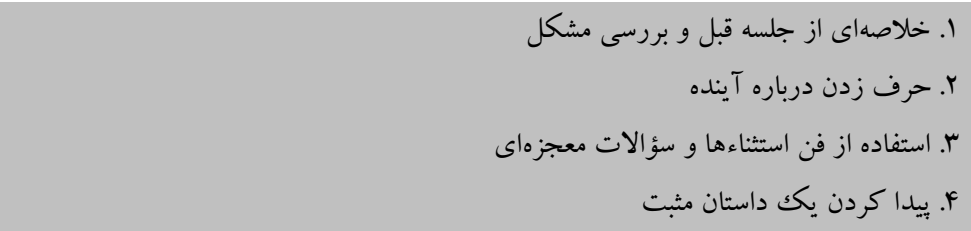 & جلسه سوم \\
\hline 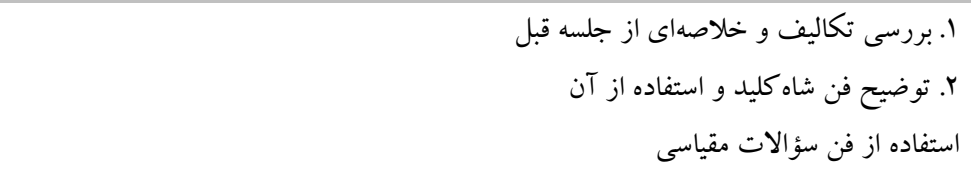 & جلسه جهارم \\
\hline 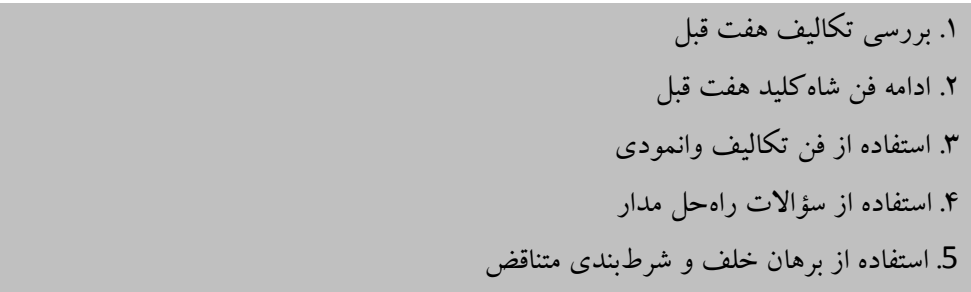 & جلسه هنجم \\
\hline 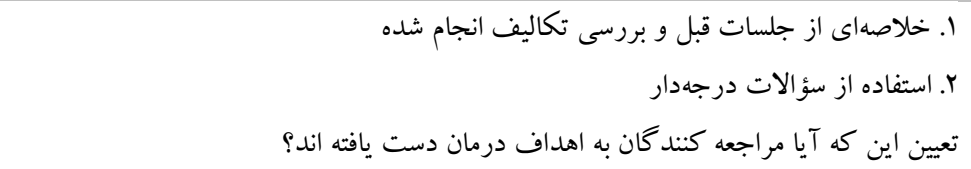 & جلسه ششم \\
\hline
\end{tabular}

مقايسه اثربخشى درمان راه حل محور و درمان عقلانىعاطفى از آزمون تعقيبى بونفرونى استفاده شد.

\section{ابزار}

در اين تحقيق سنجش علائم اضطراب اجتماعى از يرسشنامهى فوبياى اجتماعى (SPIN) در دو مرحله يشيش آزمون و بِ آزمون استفاده شد. اين مقياس نخستين
در نهايت افراد شركت كننده در گروه و گروه كنترل

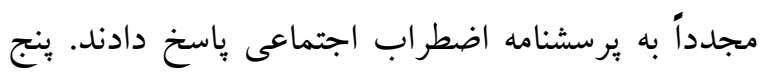

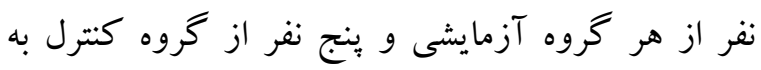
همكارى خود ادامه ندادند و حذف شدند. دادئ داده هاى به آنه دست آمده با روش تحليل كواريانس و با استفاده از نرم

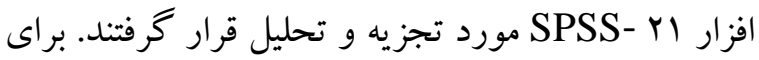


كروه نمونه شامل دانشجويان مبتلا به اضطراب اجتماعى در دانشگاه شيراز بودند كه به طور تصادفى در دو گرووه

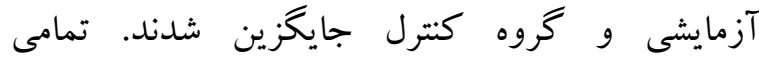
شركت كنندهها زن و از نظر تحصيلات در مقطع كارشناسى بودند. گروه سنى آزمودنىها ميانگين و انحراف معيار نمرات بيش آزمون و بس بـ آزمون اضطراب اجتماعى در سه گروه درمان عقلانى -عاطفى، درمان كو تاهمدت راه حل مدار و گروه كنترل در جدول

$$
\text { شماره ب ارائه شده است. }
$$
در بثزوهش حاضر به منظور مقايسه نمرات بس آزمون سه

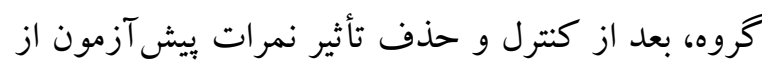
تحليل كواريانس استفاده گرديد. ييشفرضهاى استفاده از تحليل كوواريانس شامل: 1-نرمال بودن توزيع نمرات، r-همسانى واريانسهاى دو گروه آزمايش و گواه و بـ

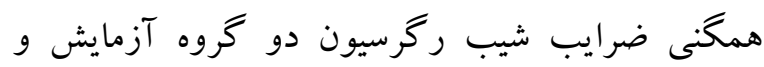
كواه مورد بررسى و تائيد قرار گرفت. جهت بررسى نرمال بودن توزيع نمرات از آزمون كولموگراف- بروني اسميرنوف استفاده شد و نتايج اين آزمون نشان داد كه توزيع نمرات اضطراب اجتماعى نرمال است. از آزمون لوين هم براى بررسى همگنى واريانس دو گروه استفاده

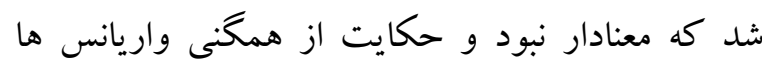

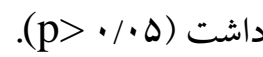
پِّ از بررسى مفروضههاى تحليل كواريانس و برقرارى مفروضهها، نمرات بس آزمون به عنوان متغير وابسته، كروه (آزمايشى اول و دوم و كنترل) به عنوان متغير مستقل و نمرات بيش آزمون به عنوان متغير كوواريت تعيين گرديد. جدول شماره F نتايج به دست آمده را كز ارش مى نمايد.
بار توسط كانور و همكاران به منظور ارزيابى اضطراب يا

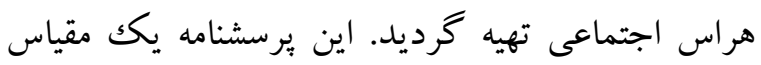
خودسنجى IV مادهاى است كه داراى سه مقياس فرعى

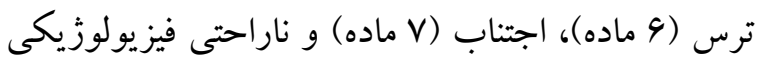
(T) ماده) هست. حسنوند، عموزاده و همكاران، ضريب

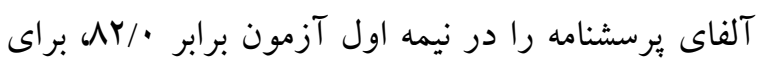

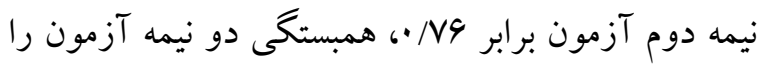

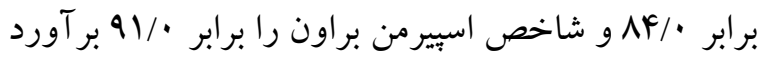

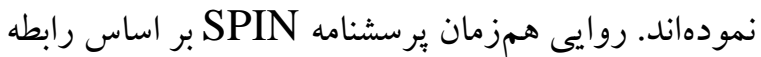
آن با اضطراب فوبيك از نسخه تجديدنظر شده جّك

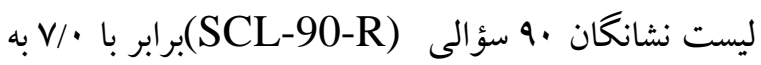
دست آمد كه بيانگر روايى مناسب آزمون است(حسنوند

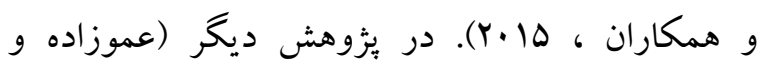
جسلى هُ با. (Y)، آلفاى كرونباخ خرده مقياس هاى سياهه

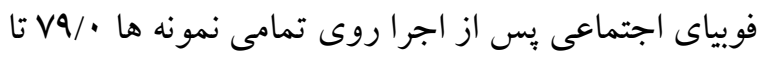

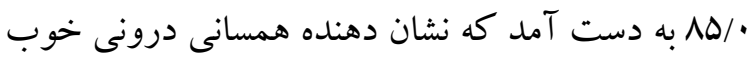

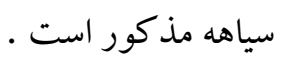
با دارا بودن ويز گیىهاى باثبات روانسنجى مىتواند بهعنوان يكك ابزار معتبر براى سنجش علائم اختلال اضطراب اجتماعى به كار رود و با توجه به اين

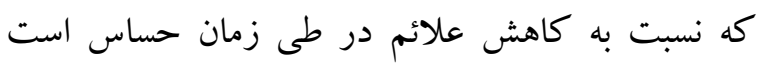
مى تواند به عنوان يكك ابزار غربالكرى و نيز براى آزمودن باسخ به درمان در اختلال اضطراب اجتماعى و يا تميز دادن درمانهايى با كارآيى متفاوت به كارگرفته شود

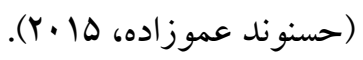

يافته ها

\section{${ }^{5}$ Chesly}


جدول م ميانكين و انحر اف معيار نمرات ييش آزمون و يس آزمون اضطراب اجتماعى در سه كروه

\begin{tabular}{|c|c|c|c|c|c|c|}
\hline \multicolumn{3}{|c|}{ يس آزمون } & \multicolumn{3}{|c|}{ يِش آزمون } & \multirow[t]{2}{*}{ كروه } \\
\hline انحر اف استاندارد & ميانكين & تعداد & انحر اف استاندارد & ميانكين & تعداد & \\
\hline$\mu \cdot / r$ & $9 \cdot / 1 V$ & 1. & $Y F / \Lambda$ & $r \cdot / \mu$ & 1. & درمان عقلانى -عاطفى \\
\hline$\Delta N / F$ & $\cdots / r \Delta$ & 1. & $19 / 0$ & $19 / 49$ & 1. & درمان راه حل مدار \\
\hline $9 F / \Lambda$ & $r \cdot / \mu^{4}$ & 9 & $9 \vee / V$ & $r \cdot / r V$ & 9 & كنترل \\
\hline
\end{tabular}

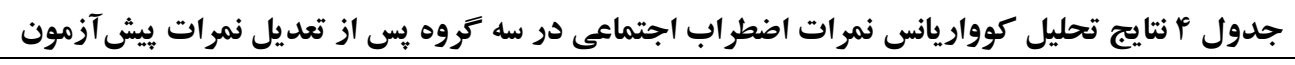

\begin{tabular}{|c|c|c|c|c|c|c|}
\hline مجذور اتا & معنادارى (P) & $\mathbf{F}$ & مجذورات ميانكين & درجه آزادى & منبع تغييرات & متغير \\
\hline$\cdot / \mathrm{NI}$ & $\cdots /$ & $. r / 91$ & $\cdot \Delta / V \cdot F$ & 1 & بيش آزمون & اضطراب اجتماعى \\
\hline$\cdot / A V$ & $\cdots / \cdot$ & $V N / N I$ & $91 / 94 \pi$ & r & عضويت گروهى & \\
\hline
\end{tabular}

نتايج جدول f نشان مىدهد با حذف تأثير نمرات بيش آزمون، بين ميانگين تعديلشده نمرات اضطراب تعديل شده يرداخته شده است. آزمون تعقيبى با استفاده اجتماعى (يس آزمون) برحسب عضويت گروهى تفاوت از شيوه بونفرونى براى كنترل خطاى نوع اول محاسبه معنادارى مشاهده مىشود. با توجه به وجود تفاوت شده و نتايج در جدول هارائه شده است.

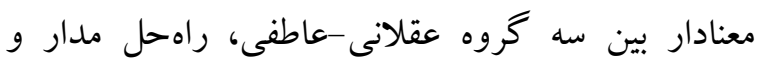

\begin{tabular}{|c|c|c|c|c|}
\hline معنادارى & خطاى استاندارد & تفاوت ميانكينها & كروه مورد مقايسه & كروه مبنا \\
\hline$\cdots /$ & $\Delta 9 / 1$ & $-\Lambda / \Gamma)$ & درمان راه حل مدار & درمان عقلانى_عاطفى \\
\hline$\cdot / \cdots$ & $\Delta r / I$ & $-r q / 19$ & كروه كنترل & \\
\hline$\cdots /$ & $\Delta 9 / 1$ & $-\cdot N / 11$ & گروه كنترل & درمان راه حل مدار \\
\hline
\end{tabular}

اجتماعى مؤثر است. هم جنين با توجه به ميانخين هاى نتايج جدول ه نشان مى دهد كه بين نمرات يس آزمون تعديل شده، بين نمرات اضطراب اجتماعى دو كروه راه اضطراب اجتماعى دو گروه درمان عقلانى-عاطفى و حل مدار و عقلانى عاطفى تفاوت معنادار وجود دارد. درمان راه حل مدار با گروه كنترل تفاوت معنادار وجود دارد؛ بنابراين هر دو درمان در كاهش علائم اضطراب 
به علاوه نتايج حاكى از برترى معنادار درمان گروهى راه بحث حل مدار در كاهش نشانهاى اضطراب اجتماعى است. به دليل اين كه هر دو گروه را درمانگران يكسانى هدايت كردند تا اثر تفاوتهاى شخصيتى درمانگران مختلف خنثى گردد، اين تفاوت در ميزان بهبودى نمى تواند از اثر درمانكر نشانهاى ناشى شده باشد، لذا مى توان كفت كه اين تفاوت آمارى بهدست آمده، ناشى از تفاوت در اثربخشى دو روش درمانى مذكور بوده

در تبيين يافتهاى فوق مىتوان به تأثير فرمت درمان كروهى و نقش آن در يِيامد درمانى اشاره نمود. درمان كروهى براى تحقق مفاهيم و اهداف خاص مدل راهحل مدار مناسبتر است. بين موضوعات مورد تمركز در اضطر اب اجتماعى و فعاليتهاى گروهى همخوانى بالايى وجود دارد. جند رفتار از نقش اجتماعى مطلوب (به عنوان مثال خود افشايى مسائل شخصى، ابراز نيازها و...)

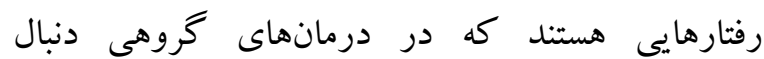
مىشوند و روى آنها تمرين مىشود. با اين وجود تحقيقات متعددى كه در زمينه مقايسه درمان شناختى رفتارى گروهى و انفرادى صورت گرفته است، به يافتهاى متناقضى منتج شده است (طاولى و همكاران، Y(Y). دو مطالعه كه به بررسى اثربخشى شناخت

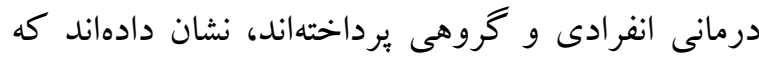
شناخت درمانى در فرمت گروهى در مقايسه با فرمت انفرادى اثربخشى كمترى در يى دارد (مورتبركى

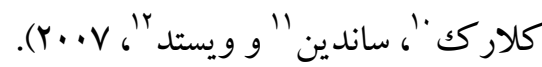

${ }^{9}$ Mortberg

${ }^{10}$ Clark

${ }^{11}$ Sundin

${ }^{12}$ Wistedt
هدف اصلى يثوهش حاضر، بررسى و مقايسه اثر بخشى درمان گروهى عقلانى عاطفى و درمان راه حل مدار به شيوه گروهى در كاهش نشانهاى اضطراب اجتماعى بود. يافتهها حاكى از اثربخشى درمان راهحل محور در درمان نشانهاى اضطراب اجتماعى است. يافته هاى مطالعات بيشين نيز اثربخشى درمان راهحل محور كوتاهمدت را در درمان اختلالات اضطرابى وافسردگى (هانگگ

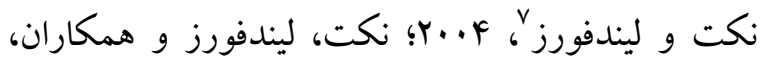

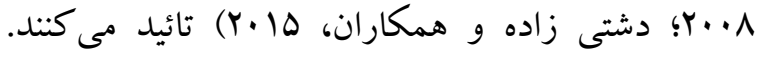
هر جند با توجه به اطلاعات نويسنده، تاكنون مطالعهاى، به طور خاص، به اثربخشى اين درمان بر اختلال اضطراب اجتماعى نبرداخته است. طبق نتايج يكك مطالعه مرورى

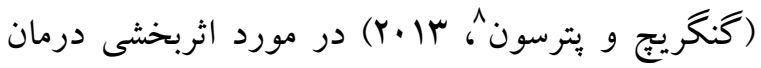
راه حل مدار، VF٪ از بثوهش هاى بررسى شده اثربخشى معنادار مثبت و سץ/ روند تغييرات مثبت را گزارش كردند و تنها يكك مطالعه تأثير قابلمشاهدهاى را خزارش

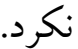
يافته ها همجتين نشان داد كه درمان عقلانى-هيجانى بر نشانه هاى اضطراب اجتماعى مؤثر بوده است. مطالعات ييشين از اثربخشى درمانهاى شناختى رفتارى در درمان اختلال اضطراب اجتماعى حمايت مى كنند (حيدريان فرد، بخشى يور و فرامرزى، ها ·r؛ رضايى، اميرى و

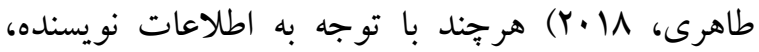
تاكنون مطالعهاى به طور خاص اثربخشى درمان عقلانى عاطفى بر اختلال اضطراب اجتماعى را بررسى نكرده 
اضطر اب اجتماعى، شامل بيماران جنس مذكر و به ويثه بيماران مراجعه كننده به مراكز روان درمانى را كه از علائم شديدتر و اختلالات همراه بيشتر رنج مىبرند، محدود نمايد .ازاين رو تكرار مطالعه حاضر در جامعه بالينى مىتواند مقايسه بهتر نتايج و تعميميذيرى يافتها

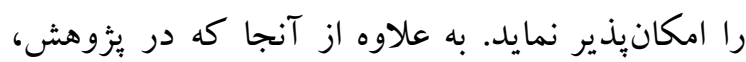

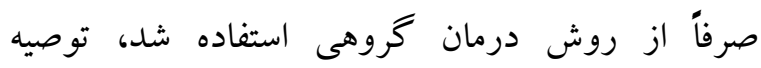
مىشود مقايسه اثربخشى اين دو درمان در قالب درمانهاى انفرادى نيز مورد بررسى قرار گيرد و نتايج فردى و گروهى با يكديگر مقايسه شوند.

\section{نتيجه كيرى}

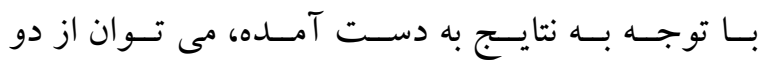
درمان گروهى راه حل محور و عقلانى-عاطفى بـه

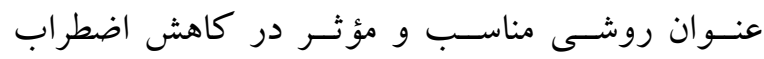
اجتماعى دانشجويان اسـتفاده نمـود. هر جند با توجه به نتيجه مطالعه حاضر درمان گروهى راه حل محور اثربخشى بيشترى را در عمل نشان داد اما براى نتيجه

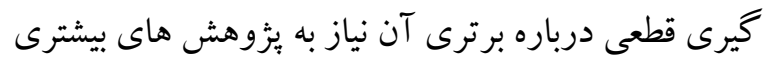

سياسگز ارى

بدينوسيله از تمامى افرادى كه با حضور خود در اين يُزوهش ما را يارى كردند، سياسگز ارى به عمل مى آيد.

\section{References}

Amouzadeh MH. (2015). The standardization of social phobia inventory (SPIN) in nonclinical Iranian samples. Urmia Medical Joumal, 26, 17-30.

Amouzadeh MH, \& Chesly RR. (2013). Association of brain-behavioral systems activity and gender
مىتوان كفت از آن جا كه تمركز CBT بيشتر به

صورت درون روانى است كه تناسب كمترى با با بـ فعاليتهاى گروهى دارد. اين در حالى است كه يكى از

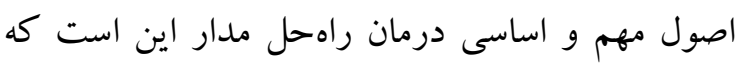
راهحلهايى كه فرد تاكنون نتوانسته ييدا كند به وسيلهى ديخران خلق شوند و اين اصل در گروه بهتر ممكن مى كردد. از طرفى، تمركز درمان راهحل مدار توانايىهاى خود مراجع، كثف راهحل و استثنائات بوده و تأكيد بر

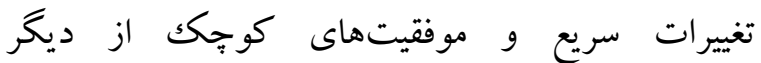
ويز گیىهاى اين درمان است؛ بنابراين ممكن است به دليل ماهيت درمان راهحل مدار، سرعت كاهش علائم در اين نوع درمان بيشتر باشد اما احتمال دارد نتايج درمانى در طولانىمدت بايدار نباشند و بهتدريج علائم جانشين يكديخر شوند. در درمان شناختى تفكر بيمار آماج درمان قرار مى گيرد و تغيير خطاهاى شناختى و از همه مهم تأثير گذارى بر روى باورهاى اساسى و هستهاى منفى بيمار، شيوه مداخلهاى اصلى در درمان شناختى است و به نظر مىرسد اين مسئله منجر به شروع ديرتر و درعين حال تداوم تأثيرات درمانى براى مدتى طولانىتر مىشود؛ بنابراين عدم ارزيابى ييخيرى يككساله جهت مقايسه نرخ تداوم بهبودى در دو روش درمانى يكى از محدوديتهاى اين مطالعه است و انجام آن در مطالعات متعاقب امكان اظهارنظر قطعى در مورد بايدارى اثرات درمانى دو روش راهحل مدار و عقلانى -عاطفى را فراهم مىنمايد. محدوديت ديخر اين إثوهش محدود بودن نمونه موردبررسى به دانشجويان دختر است كه ممكن است تعميم يافتهاى آن به ساير بيماران مبتلا به اختلال 
with social anxiety. Pajoohandeh Joumal, 18, 114-121.

Dashtizadeh N, Sajedi H, Nazari A, Davarynia R, \& Shakarami M. (2015). Effectiveness of Solution-Focused Brief Therapy (SFBT) on Reducing Symptoms of Depression in Women. Joumal of Clinical Nursing and Midwifery, 4, 67-78.

Ghadedee KAK, Habibi M. (2015). Effectiveness of solution - focused brief therapy on reducing depression in women under protectship of state welfare organization of Iran. Joumal of Research in Behavioural Sciences, 13, 431440.

Ghaedi GH, Tavoli A, Bakhtiari M, Melyani M, \& Sahragard M. (2010). Quality of life in college students with and without social phobia. Social indicators research, 97, 247-256

Gingerich WJ, \& Peterson, LT. (2013). Effectiveness of solution-focused brief therapy: A systematic qualitative review of controlled outcome studies. Research on Social Work Practice, 23(3), 266-283.

Habibi M. (2015). Solution-oriented therapy for depression: A theoretical orientation and introduction to therapeutic approach. Joumal of Research in Behavioural Sciences, 13, 166175.

Heidarian Fard Z, Bakhshipour B, Faramarzi M. (2015). The effect of cognitive behavioral therapy on social womiment, social autonomous and intellectual champ in students with social worriment disorder in Iran. Journal of Clinical Psychology Studies, 6(21), 152-75.

Huang MK. (2001). A comparison of three approaches to reduce

marital problems and symptoms of depression (Unpublished Dissertation). University of Florida, FL.

Knekt P, \& Lindfors O. (Eds.). (2004). A randomized trial of theeffect of four forms of psychotherapy on depressive and anxiety disorders (Vol. 77). Helsinki, Finland: The Social Insurance Institution.

Knekt P, Lindfors O, Laaksonen MA, Raitasalo R, Haaramo P, \& Jarvikoski, A. (2008). Effectiveness of short-term and longterm psychotherapy on work ability and functional capacity -Arandomized clinical trial on depressive and anxiety disorders. Journal of Affective Disorders, 107,95-106.

Kim JS, \& Franklin C. (2009). Solution-focused brief therapy in schools: A review of the outcome literature. Children and Youth Services Review, 31,464470.

Mortberg E, Clark D, Sundin Ö, \& Åberg Wistedt A. (2007). Intensive group cognitive treatment and individual cognitive therapy vs. treatment as usual in social phobia: a randomized controlled trial. Acta Psychiatrica Scandinavica, 142-154.

Rezaie F, Amiri M, Taheri E. (2018). Effectiveness of cognitive-behavioral group therapy on reducing docial anxirty and negative cognitive evaluation among hard of hearing hard girls. Counceling Culture and Psychotherapy, 8(23), 133-160.

Tavoli A, Allahyari A, Azadfalah P, Fathi-Ashtiani A, \& Melyani M. (2013). A Comparison of the effectiveness of interpersonal and cognitive behavioral therapies for social anxiety disorder. Intemational Joumal of Behavioral Sciences, 7,199-206.

Taylor S. (1996). Meta-analysis of cognitive-behavioral treatments for social phobia. Joumal of behavior therapy and experimental psychiatry, 27,1-9.

Wittchen HU, Stein MB, \& Kessler RC. (1999). Social fears and social phobia in a community sample of adolescents and young adults: prevalence, risk factors and co-morbidity. Psychological Medicine, 29(2), 309-23. 